Acknowledgements. We would like to express our appreciation of the excellent work of the pilots from Greenlandair A/S during the EMR survey at Isortuarssûp tasia, and the logistic support by the GGU base camp at Atâ and the camp on the ice. Much of the computer treatment of these data was undertaken by Mette Svane Jørgensen and Dorthe Nyland Sørensen, GGU.

\section{References}

Kalsbeek, F. 1989: GGU's expedition in the Disko Bugt area, 1988. Rapp. Gronlands geol. Unders. 145 (this volume).

Thomsen, H. H., Olesen, O. B., Braithwaite, R. J. \& Weidick, A. 1989: Greenland ice-margin programme, a pilot study at Pâkitsoq, north-east of Jakobshavn, central West Greenland. Rapp. Grønlands geol. Unders. 145 (this volume).

Thorning, L., Thomsen, H. H. \& Hansen, E. 1986: Geophysical investigations at the Inland Ice margin of the Pâkitsoq basin, central West Greenland. Rapp. Grønlands geol. Unders. 130, 114-121.

Thorning, L. \& Hansen, E. 1987: Electromagnetic reflection survey 1986 at the Inland Ice margin of the Pâkitsoq basin, central West Greenland. Rapp. Grønlands geol. Unders. 135, 87-98.

Thorning, L. \& Hansen, E. 1988a: Construction and testing of a lightweight radar for ice-thickness determination on glaciers in the Pâkitsoq area, central West Greenland. Rapp. Gronlands geol. Unders. 140, 118-121.

Thorning, L. \& Hansen, E. 1988b: Electromagnetic reflection survey 1987 in key areas of the Pâkitsoq basin at the margin of the Inland Ice, central West Greenland. Rapp. Grønlands geol. Unders. 140, 117-118.

L. T. \& E. H., Grønlands Geologiske Undersøgelse, $\emptyset$ ster Voldgade 10 , $D K-1350$ København $K$, Danmark.

\title{
Improved accumulation measurements on Glacier 1CG14033 near Nuuk/Godthåb, West Greenland
}

\author{
Roger J. Braithwaite and Henrik Højmark Thomsen
}

Glacier 1CG14033 is a small $\left(1.1 \mathrm{~km}^{2}\right)$ glacier located in the Kangerluarsunnguaq or Buksefjorden basin, which is a possible site for a hydropower station to supply energy to Nuuk/Godthåb (fig. 1). Glaciers only occupy $1-2 \%$ of the basin area (Weidick \& Thomsen, 1983), but glaciological measurements have been made since 1982 to investigate the possible effects of glaciers on runoff and to contribute to GGU's programme of regional glaciology.

\section{Measurements 1982-1987}

Eight aluminium stakes were drilled into the glacier in 1982 and have been used for rudimentary mass-balance measurements during twice-yearly visits of a few hours by helicopter. The winter snow accumulation is determined in May by measuring snow depths at all stakes and measuring snow density in snowpits of 1-3 m depth at some stakes. The summer ablation is determined in late August or early September at the lowest stakes by measuring the lowering of the ice surface relative to the stakes. However, snow ablation at higher stakes is more difficult to measure as most water from snow melt refreezes at depth in the snowpack, possibly a few metres below the surface. Brief twice-yearly visits made in the period 1982-1987 never allowed time to dig or core throughout the whole wet snow layer. With the reduction in activity at Qamanârssûp sèrmia since 1986 (Braithwaite, 1987) it was possible to plan a longer stay on the glacier in May 1988 to improve the accumulation measurements.

\section{The 1988 measurements}

A lightweight camp was established on the glacier as a base for the measurements in the period 5-8 May 1988. Camping equipment was as light as possible to allow a single flight with a Bell-206 Jet Ranger helicopter but was inadequate at temperatures of $-20^{\circ} \mathrm{C}$. Future operations will need at least two helicopter flights to establish camp.

A total of three deep snow pits were dug for density measurements, which is a great improvement on earlier years. Another improvement, although time-consuming, was the use of a GEOTEST ramsonde to measure hardness profiles in the snowpack. The hard 'summer surface' of 1987 could be more easily detected in this way than by using the standard GGU snow probe as in previous years.

Unfortunately only a brief visit could be made on 23 August to make stake readings adequate for calculating net ablation at stakes 1,2,4 and 7, but there was not enough time to measure the density profiles at stakes 5 , 6 and 8 , which are needed to calculate net ablation. It is 


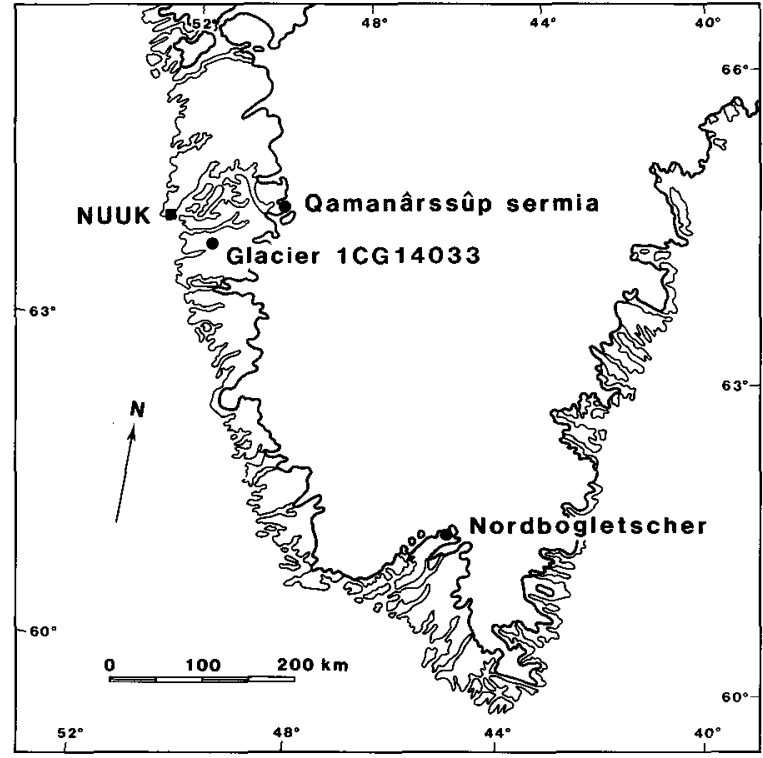

Fig. 1. Map showing location of Glacier 1CG14033 in relation to Qamanârssûp sermia and Nordbogletscher.

hoped that these can be measured in May 1989 using a SIPRE corer if another 3-day camp is established on the glacier.

\section{Data 1982-1988}

The available data for seven years for winter accumulation and net ablation are summarized in Table 1.
Winter accumulation is calculated for all stakes for which snow depths were measured. For most years snow densities were extrapolated from a single snow pit compared with three snow pits in 1988. Measurements of snow depth in 1988 are also better when compared to previous years, due to use of the ramsonde. The data for many stakes in 1986, and for stake 8 in two other years, are missing because these stakes were buried by deep snow. Stake 3 has totally disappeared, presumably due to burial.

Net ablation data are only available for stakes in the ablation area (stakes $1 \& 7$ ) or for situations where snowpits and/or cores were made sufficiently deep to measure refreezing (stakes $2 \& 4$ ).

The time-variations in accumulation and net ablation are best studied by calculating indices which are averages of the available data (Braithwaite \& Olesen, in press 2), although conclusions must be made cautiously because of the few stakes and shortness of records. Indices of accumulation and net ablation are given in Table 2. The accumulation index is the time-variation of average accumulation at stakes $2,5,6 \& 7$ (missing data for 1986 at stakes $5 \& 6$ are interpolated by correlations with data at stakes $2 \& 7$ ). The net ablation index is the time-variation of average net ablation at stakes $1,2,4 \&$ 7.

Accumulation has much lower variability than net ablation with standard deviations of \pm 0.13 and \pm 0.56 $\mathrm{m}$ water respectively for the two series in Table 2 . These are in reasonable agreement with standard deviations of \pm 0.09 and $\pm 0.53 \mathrm{~m}$ water for accumulation and net

Table 1. Summary of mass-balance measurements at eight stakes, Glacier 1GC14033, West Greenland

\begin{tabular}{|c|c|c|c|c|c|c|c|c|}
\hline \multirow[b]{2}{*}{ Year } & \multicolumn{8}{|c|}{ STAKES } \\
\hline & 1 & 2 & 3 & 4 & 5 & 6 & 7 & 8 \\
\hline \multicolumn{9}{|c|}{ Winter accumulation } \\
\hline $1981 / 82$ & 0.48 & & & & & & & \\
\hline $1982 / 83$ & & 0.74 & & & 0.91 & 0.83 & 0.67 & \\
\hline $1983 / 84$ & & 0.70 & 0.73 & 0.76 & 0.93 & 0.89 & 0.56 & \\
\hline $1984 / 85$ & 0.59 & 0.68 & 0.39 & 0.46 & 0.43 & 0.51 & 0.37 & 0.38 \\
\hline $1985 / 86$ & 0.56 & 0.96 & & & & & 0.6 & \\
\hline $1986 / 87$ & & 0.50 & & 0.23 & 0.82 & 0.86 & 0.69 & 0.90 \\
\hline $1987 / 88$ & 0.82 & 0.78 & & 0.81 & 0.88 & 0.95 & 0.31 & 0.98 \\
\hline \multicolumn{9}{|c|}{ Net ablation } \\
\hline $1981 / 82$ & 0.60 & & & & & & & \\
\hline $1982 / 83$ & -0.03 & -0.59 & -0.60 & -0.62 & & & -0.38 & \\
\hline $1983 / 84$ & 0.02 & 0.09 & -0.27 & -0.03 & & & 0.36 & \\
\hline $1984 / 85$ & 1.62 & 1.06 & & 0.68 & & & 1.58 & \\
\hline $1985 / 86$ & 0.58 & -0.30 & & -0.14 & & & 0.44 & \\
\hline $1986 / 87$ & 0.47 & 0.36 & & 0.03 & & & 1.04 & \\
\hline $1987 / 88$ & -0.05 & -0.07 & & -0.21 & & & 0.22 & \\
\hline
\end{tabular}

Units are metres water equivalent 
Table 2. Indices of accumulation and net ablation on Glacier 1CG14033, West Greenland

\begin{tabular}{lcc}
\hline Year & $\begin{array}{c}\text { Accumulation } \\
\text { index } \\
\text { (4 Stakes) }\end{array}$ & $\begin{array}{c}\text { Net ablation } \\
\text { index } \\
\text { (4 Stakes) }\end{array}$ \\
\hline $1982 / 83$ & 0.04 & -0.67 \\
$1983 / 84$ & 0.02 & -0.15 \\
$1984 / 85$ & -0.25 & 0.98 \\
$1985 / 86$ & 0.09 & -0.11 \\
$1986 / 87$ & 0.03 & 0.22 \\
$1987 / 88$ & 0.08 & -0.29 \\
& & \\
Std dvn & \pm 0.13 & \pm 0.56 \\
\hline
\end{tabular}

Units are metres water equivalent

ablation series from Nordbogletscher (Braithwaite \& Olesen, in press 1$)$, and with $\pm 0.56 \mathrm{~m}$ water for net ablation on Qamanârssûp sermia (Braithwaite \& Olesen, in press 2). However, this basic pattern of low variability for accumulation and high variability for net ablation contradicts the assumption of equal variability by Braithwaite (1982).

\section{Some results}

There is a strong negative correlation between net ablation and accumulation indices, illustrated in fig. 2, which agrees with results from Nordbogletscher and reflects the lower thermodynamic efficiency of snow ablation compared with ice ablation at the same temperature (Braithwaite \& Olesen, in press 1). This has implications for the existence of Glacier 1CG14033. For example, the elevation range of the glacier is very limited, so that air temperature is fairly constant over the glacier, and the accumulation area probably exists because

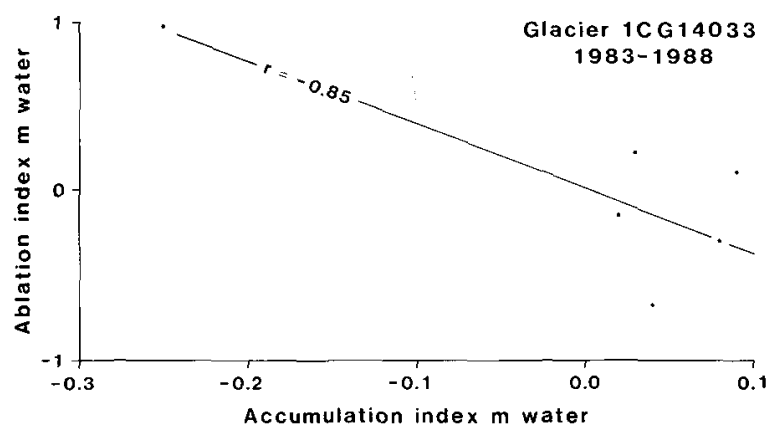

Fig. 2. Ablation index versus accumulation index for Glacier $1 C G 14033$.

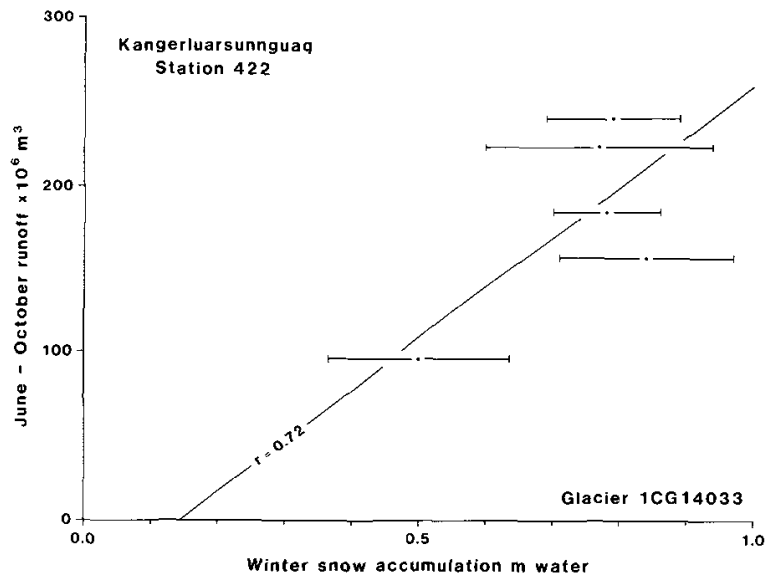

Fig. 3. June-October runoff from the Kangerluarsunnguaq basin versus winter snow accumulation on Glacier 1CG14033.

topographic concentration of winter snow reduces summer ablation. For example, according to the regression line in fig. 2, an accumulation increase of only $0.1 \mathrm{~m}$ water reduces net ablation by $0.38 \mathrm{~m}$ water.

Glacier cover in the Kangerluarsunnguaq basin is too sparse for glaciers to have any marked effect on runoff in the sense of Braithwaite \& Olesen (1988), but there is a positive correlation between winter snow accumulation on Glacier 1CG14033 and runoff as measured by the Greenland Technical Organization (GTO, 1986). The correlation in fig. 3 between winter snow accumulation and June-October runoff for the five years 19831987 shows that accumulation measurements in May can forecast runoff in the following summer, as already pointed out for Johan Dahl Land by Braithwaite \& Olesen (in press 1). This does not mean that Glacier 1CG14033 has any effect on the runoff from the whole basin but rather that snow accumulation on the glacier is an index of snow accumulation elsewhere in the basin.

\section{Outlook}

The 1988 work confirms that accumulation measurements can be improved by a longer stay on the glacier in the spring, and presumably net ablation measurements would similarly benefit from a longer stay in late August. Accumulation data from the glacier are useful for seasonal forecasting of runoff from the Kangerluarsunnguaq basin. Continuation and improvement of the measurements on Glacier 1CG14033 would be useful therefore for planning, and eventual operation, of hydropower for Nuuk/Godthåb.

Acknowledgements. Dr J. Oerlemans, University of Utrecht, helped RJB with the measurements in August 1988. Unpub- 
lished runoff data for the Kangerluarsunnguaq basin were provided by the Section for Hydro-technical Investigations, Greenland Technical Organization.

\section{References}

Braithwaite, R. J. 1982: A simple model of runoff from ungauged basins in West Greenland. Rapp. Grønlands geol. Unders. 111, 26 pp.

Braithwaite, R. J. 1987: The last full summer of glacier-climate investigations at Qamanârssûp sermia, West Greenland. Rapp. Grønlands geol. Unders. 135, 95-98.

Braithwate, R. J. \& Olesen, O. B. 1988: Effect of glaciers on annual run-off, Johan Dahl Land, South Greenland. J. Glaciol. 34, 200-207.

Braithwaite, R. J. \& Olesen, O. B. in press 1: Winter accumulation reduces summer ablation on Nordbogletscher, South Greenland. Z. Gletscherk. Glazialgeol. 24.
Braithwaite, R. J. \& Olesen, O. B. in press 2: Detection of ablation signal by inter-stake correlation of annual ablation data, Qamanârssûp sermia, West Greenland. J. Glaciol.

GTO 1986: Generelle hydrologiske bassin informationer: bynære bassiner 1986, supplement 1, 113 pp. Copenhagen: Grønlands Tekniske Organisation.

Thomsen, H. H. \& Braithwaite R. J. 1987: Use of remote sensing data in modelling runoff from the Greenland ice sheet. Ann. Glaciol. 9, 215-217.

Weidick, A. \& Thomsen, H. H. 1983: Lokalgletschere og Indlandsisens rand $\mathrm{i}$ forbindelse med udnyttelse af vandkraft i bynære bassiner. Gronlands geol. Unders. Gletscher-hydrol. Meddr 83/2, 129 pp.

R. J. B. \& H. H.T., Grønlands Geologiske Undersøgelse, Øster Voldgade 10, DK-1350 København K, Danmark.

\title{
Evaluation of the niobium-tantalum potential of the Motzfeldt Centre, South Greenland
}

\author{
Bjørn Thomassen
}

The Motzfeldt 87 Project, initiated in June 1987, was completed in May 1988 with the publication of the final report (Thomassen, 1988). The project consisted of a detailed investigation of selected parts of the niobiumtantalum-uranium-bearing pyrochlore mineralisation at Motzfeldt Sø, South Greenland (fig. 1). The purpose of the project was to gain a general impression of the metal distribution in the mineralised zones and to delineate areas with high metal contents. The project was carried out as a joint programme between GGU and Nunaoil A/S under the supervision of GGU, and was mainly funded by the Mineral Resources Administration for Greenland.

The field work in July and August 1987 involved twenty persons and comprised an airborne gamma-spectrometric survey, a major chip sampling programme and minor reconnaissance (Thomassen \& Tukiainen, 1987; Thomassen et al., 1988). The subsequent laboratory work covered lithological logging and chemical analysis of chip samples, statistical treatment of analytical results, and preparation of geophysical and geochemical anomaly maps (Thomassen, 1987, 1988).

During the project the following contractors were employed: Greenlandair Charter A/S (helicopter support); Global Earth Sciences Ltd., England (airborne gamma-spectrometric survey); Garaventa AG., Swit- zerland (mountaineering team); Bondar-Clegg \& Co. Ltd. and Chemex Labs Ltd., both Canada (chemical analyses); and IMSOR Image Processing Group, Technical University of Denmark (statistical analysis).

\section{Geology and mineralisation}

The $c .300 \mathrm{~km}^{2}$ Motzfeldt Centre belongs to the Proterozoic alkaline Gardar province in South Greenland. The centre was mapped geologically in the period 19611970 by GGU geologists (Emeleus \& Harry, 1970), and in the period 1979-1985 GGU expeditions, partly funded by the European Economic Community, discovered and investigated a widespread pyrochlore mineralisation (Armour-Brown et al., 1980; Armour-Brown et al., 1983; Tukiainen et al., 1984; Tukiainen, 1986, 1988).

The Motzfeldt Centre consists of syenites and nepheline syenites which were intruded into the Proterozoic Julianehåb granite and Gardar supracrustal rocks some $1310 \mathrm{Ma}$ ago. The main igneous phase is composed of a number of concentric, steep-sided, outward dipping units of peralkaline rocks. In the outermost of these units, the Motzfeldt Sø Formation, large quantities of roofing sandstones and volcanics have been incorporated. The volcanics are preserved as rafts, whereas the sandstones have been assimilated and have created an 